\title{
Study Skills assessment among Medical Undergraduates - Where they stand?
}

\author{
Dr. Madhavi S. ${ }^{1}$, Dr. SAppala Naidu ${ }^{2}$, Dr. A. Krishnaveni ${ }^{3}$, Dr. Kiran P. ${ }^{4}$ \\ 1. Assistant Professor, ${ }^{2}$ Professor\& Head, ${ }^{3 .}$ Professor, ${ }^{4}$ Resident, Department of Community Medicine, \\ Andhra Medical College, Visakhapatnam.
}

\begin{abstract}
:
Introduction: Medical education is facing a lot of new challenges today. Education among medical students is perceived to have declined largely in recent years. Objective: To assess the study skills among final year MBBS students.Materials and methods: A descriptive cross- sectional study was done on 'Study skills assessment' among 137 Final MBBS students of Andhra Medical College, Visakhapatnam, Andhra Pradesh. Out of 137 students, 125 students who filled in the questionnaire completely were included in the study. Pre tested, modified, self-administered questionnaire which has been adapted from 'DENIS CONGO STUDY SKILLS INVENTORY' was used.Data was analyzed using MS excel and relevant statistical tests were applied. Results: Out of 125 students, 58 were boys and 67 were girls. 82 students were hostellers while 43 were Day scholars. While reading a text book, only 11 (9\%)students said that they almost always formulate questions before, during or after reading the text book. Only three students stated that they do not use mnemonics while all others stated that they use mnemonics some or other time while learning. When the domains were assessed gender wise, the mean score for notes taking was higher among females $(11.32 \pm 3.19)$ than males $(8.79 \pm 3.28)$ and this difference was found to be statistically significant. Recommendation:Study skills among students can be improved further by better time management and test preparation. Applying study skills leads to better student learning.
\end{abstract}

Key words: medical students, medical education, study skills assessment

\section{Introduction}

Under graduate medical education is facing many new challenges in India.Upon graduation,medical students are expected to have developed enough competency in medical knowledge and clinical skills.In spite of the best teachers applied to the medical students, performance of students as well as doctors in the community is perceived to have largely declined.$^{(1)}$ It is well known that it takes lot of hard work, stress and rigorous training to become a good doctor.Medical students need to learn huge volumes of different subjects for better academic results. Study skills are one important factor which influences the academic performance of students.Bloom believes that study skills are pre-requisite for educational success ${ }^{(2)}$.Students have different study skill practices which are based on their study habits,their interest in subject and type of learning they follow from schooling. In this context, the present study was done to assess the study skills among final year MBBS students.

\section{Materials And Methods}

A descriptive cross- sectional study was done on 'Study skills assessment' among 137 Final MBBS students of Andhra Medical College, Visakhapatnam, Andhra Pradesh. The class strength was 153, of which 137 who were present on the day of data collection, participated in the study. Out of 137 students, 125 students who filled in the questionnaire completely were included in the study. Pre tested, modified, self-administered questionnaire which has been adapted from 'DENIS CONGO STUDY SKILLS INVENTORY' was used. ${ }^{(3)}$ DCSSI is a validated study skills inventory questionnaire. It consists of six domains namely Text book reading, Notes taking, Memory, Test preparation, Concentration and Time management.Each of these six domains had 4 to 10 components which were assessed using sentences to compositely indicate each component on a five point rating scale.Responses were scored as follows: 1 - Almost never, 2 - Less than half of the time, 3 - About half of the time, 4 - More than half of the time, 5 - Almost always.Data was analysed using MS Excel. Standard tests for descriptive statistics were applied, which commonly included the use of percentages. Association between gender and domain parameters was done using $\mathrm{Z}$ test. $P$-value of less than 0.05 was considered to be statistically significant.

\section{Results}

Out of 125 students who participated in the study,58 were boys and 67 were girls. About 82 students were hostellers while 43 were staying outside the hostel with parents or relatives. 
Responses of students under 6 domains(text book reading 6 questions, notes taking 5 questions, memory 5 questions, test preparation 8questions, concentration 7 questions and time management 4 questions) were obtained as shown in the following tables.

Table 1: Response of students to Text book Reading

\begin{tabular}{|l|c|c|c|c|c|}
\hline & $\begin{array}{c}\text { Almost } \\
\text { Never }\end{array}$ & $\begin{array}{c}\text { Less than half of } \\
\text { the time }\end{array}$ & $\begin{array}{c}\text { About half of } \\
\text { the time }\end{array}$ & $\begin{array}{c}\text { More than half of } \\
\text { the time }\end{array}$ & $\begin{array}{c}\text { Almost } \\
\text { Always }\end{array}$ \\
\hline Formulating questions & $\mathrm{n}(\%)$ & $\mathrm{n}(\%)$ & $\mathrm{n}(\%)$ & $\mathrm{n}(\%)$ & $\mathrm{n}(\%)$ \\
\hline Surveying headings & $21(37.6)$ & $30(24)$ & $20(16)$ & $17(13.6)$ & $11(8.8)$ \\
\hline $\begin{array}{l}\text { Finding meaning of new } \\
\text { terms }\end{array}$ & $2(1.6)$ & $20(16)$ & $17(13.6)$ & $28(22.4)$ & $39(31.2)$ \\
\hline Formulating answers & $28(22.4)$ & $19(15.2)$ & $30(24)$ & $27(24.8)$ & $58(46.4)$ \\
\hline Looking for main ideas & $6(4.8)$ & $16(12.8)$ & $21(16.8)$ & $36(28.8)$ & $46(36.8)$ \\
\hline $\begin{array}{l}\text { Reading chapter more } \\
\text { than once }\end{array}$ & $9(7.2)$ & $33(26.4)$ & $27(21.6)$ & $26(20.8)$ & $30(24)$ \\
\hline
\end{tabular}

The mean score of students for Text book reading was $19.76 \pm 4.77$ with range 6-29 (The maximum possible score was 30 for this domain). Our study revealed that while reading a text book, only 11 (9\%) students said that they almost always formulate questions before, during or after reading the text book, while majority $(38 \%)$ students said that they never formulate questions while reading text book. $39(31 \%)$ students stated that they always survey headings, bold print, italics, questions etc before reading. Majority of students (46\%) said that they almost always get the meanings of new terms as they encounter them while reading text book. Only nine students said that they almost never read the chapter second time.

Table 2: Response of students for Notes taking

\begin{tabular}{|c|c|c|c|c|c|}
\hline & Almost Never & $\begin{array}{l}\text { Less than half of } \\
\text { the time }\end{array}$ & $\begin{array}{l}\text { About half of the } \\
\text { time }\end{array}$ & $\begin{array}{l}\text { More than half of } \\
\text { the time }\end{array}$ & $\begin{array}{l}\text { Almost } \\
\text { Always }\end{array}$ \\
\hline & $\mathrm{n}(\%)$ & $\mathrm{n}(\%)$ & $\mathrm{n}(\%)$ & $\mathrm{n}(\%)$ & $\mathrm{n}(\%)$ \\
\hline Notes taking while reading & $33(26.4)$ & $36(28.8)$ & $25(20)$ & $15(12)$ & $16(12.8)$ \\
\hline Reviewing of notes & $47(37.6)$ & $39(31.2)$ & $21(16.8)$ & $9(7.2)$ & $9(7.2)$ \\
\hline Rewriting lecture notes & $105(84)$ & $16(12.8)$ & $2(1.6)$ & $2(1.6)$ & $0(0)$ \\
\hline $\begin{array}{l}\text { Comparing with others notes to } \\
\text { check for accuracy }\end{array}$ & $93(74.4)$ & $20(16)$ & $4(3.2)$ & $5(4)$ & $3(2.4)$ \\
\hline
\end{tabular}

The mean score of students for Notes taking was $10.15 \pm 3.46$ with range 5-20 (The maximum possible score was 25 for this domain). 56 (44\%) students mentioned that they take notes almost always to about half the times while they read the text book. $31(25 \%)$ students mentioned that they take notes during lectures in classroom only about half the times, 19 students more than half the times and $20(16 \%)$ students mentioned that they take notes during lectures almost always. Rarely did students rewrote the lecture notes or compared with other notes to check for completeness and accuracy.

Table 3: Response of students regarding Memory

\begin{tabular}{|c|c|c|c|c|c|}
\hline & Almost Never & $\begin{array}{l}\text { Less than half of the } \\
\text { time }\end{array}$ & $\begin{array}{l}\text { About half of the } \\
\text { time }\end{array}$ & $\begin{array}{l}\text { More than half of } \\
\text { the time }\end{array}$ & $\begin{array}{l}\text { Almost } \\
\text { Always }\end{array}$ \\
\hline & $\mathrm{n}(\%)$ & $\mathrm{n}(\%)$ & $\mathrm{n}(\%)$ & $\mathrm{n}(\%)$ & $\mathrm{n}(\%)$ \\
\hline Reviewing notes for exams & $39(31.2)$ & $30(24)$ & $22(17.6)$ & $15(12)$ & $19(15.2)$ \\
\hline Using mnemonics & $3(2.4)$ & $42(33.6)$ & $25(20)$ & $30(24)$ & $25(20)$ \\
\hline Using visuals like charts & $11(8.8)$ & $19(15.2)$ & $26(20.8)$ & $37(29.6)$ & $32(25.6)$ \\
\hline $\begin{array}{l}\text { Quiz yourself } \\
\text { questions in exams }\end{array}$ & $33(26.4)$ & $34(27.2)$ & $20(16)$ & $23(18.4)$ & $15(12)$ \\
\hline $\begin{array}{l}\text { Converting lecture into own } \\
\text { words }\end{array}$ & $18(14.4)$ & $30(24)$ & $16(12.8)$ & $27(21.6)$ & $34(27.2)$ \\
\hline
\end{tabular}

The mean score of students regarding memory was $15.15+4.37$ with range $6-25$ (The maximum possible score was 25 for this domain). Only three students stated that they do not use mnemonics while all others stated that they use mnemonics some or other time while learning. 
Study Skills assessment among Medical Undergraduates - Where they stand?

Table 4: Response of students to Test Preparation

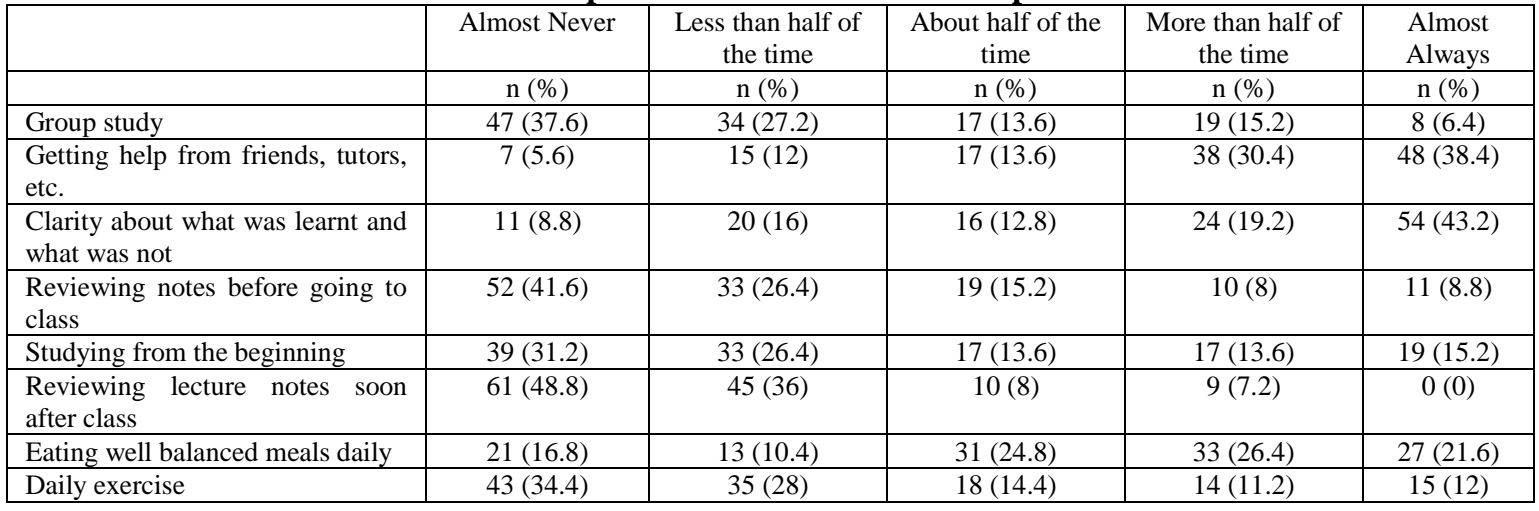

The mean score of students for Test preparation was $21.9 \pm 4.95$ with range 9-35 (The maximum possible score was 40 for this domain). Majority of the students stated that they do not prefer group study. About 48 students stated that, almost always they get help from others when they do not understand the subject. Nearly $50 \%$ of students mentioned that they almost never review lecture notes soon after class.

Table 5: Response of students about Concentration

\begin{tabular}{|c|c|c|c|c|c|}
\hline & Almost Never & $\begin{array}{l}\text { Less than half of the } \\
\text { time }\end{array}$ & $\begin{array}{l}\text { About half of the } \\
\text { time }\end{array}$ & $\begin{array}{l}\text { More than half of } \\
\text { the time }\end{array}$ & $\begin{array}{l}\text { Almost } \\
\text { Always }\end{array}$ \\
\hline & $\mathrm{n}(\%)$ & $\mathrm{n}(\%)$ & $\mathrm{n}(\%)$ & $\mathrm{n}(\%)$ & $\mathrm{n}(\%)$ \\
\hline Studying in a quiet place & $1(0.8)$ & $5(4)$ & $12(9.6)$ & $30(24)$ & $77(61.6)$ \\
\hline Taking short breaks in between & $6(4.8)$ & $12(9.6)$ & $13(10.4)$ & $28(22.4)$ & $66(52.8)$ \\
\hline Studying in the same place daily & $21(16.8)$ & $18(14.4)$ & $21(16.8)$ & $30(24)$ & $35(28)$ \\
\hline $\begin{array}{l}\text { Having all study equipment } \\
\text { handy }\end{array}$ & $11(8.8)$ & $10(8)$ & $16(12.8)$ & $28(22.4)$ & $60(48)$ \\
\hline $\begin{array}{l}\text { Break larger tasks into small } \\
\text { segments }\end{array}$ & $3(2.4)$ & $12(9.6)$ & $29(23.2)$ & $21(16.8)$ & $60(48)$ \\
\hline $\begin{array}{l}\text { Finding ways to learn an un- } \\
\text { interested subject }\end{array}$ & $7(5.6)$ & $25(20)$ & $22(17.6)$ & $41(32.8)$ & $30(24)$ \\
\hline $\begin{array}{l}\text { Not difficult to pay attention in } \\
\text { the class }\end{array}$ & $19(15.2)$ & $21(16.8)$ & $42(33.6)$ & $31(24.8)$ & $12(9.6)$ \\
\hline
\end{tabular}

The mean score of students for Concentration was $26.2 \pm 4.46$ with range 11-35 (The maximum possible score was 35 for this domain). 77 (62\%) students preferred studying where it is quiet, when trying to learn and remember something. Majority students (53\%) said that, they almost always take breaks while reading.

Table 6: Response of students regarding Time Management

\begin{tabular}{|c|c|c|c|c|c|}
\hline & Almost Never & $\begin{array}{l}\text { Less than half of the } \\
\text { time }\end{array}$ & $\begin{array}{l}\text { About half of the } \\
\text { time }\end{array}$ & $\begin{array}{l}\text { More than half of the } \\
\text { time }\end{array}$ & $\begin{array}{l}\text { Almost } \\
\text { Always }\end{array}$ \\
\hline & $\mathrm{n}(\%)$ & $\mathrm{n}(\%)$ & $\mathrm{n}(\%)$ & $\mathrm{n}(\%)$ & $\mathrm{n}(\%)$ \\
\hline Using a calendar book & $77(61.6)$ & $21(16.8)$ & $13(10.4)$ & $5(4)$ & $9(7.2)$ \\
\hline Using To-do lists & $72(57.6)$ & $20(16)$ & $12(9.6)$ & $9(7.2)$ & $12(9.6)$ \\
\hline $\begin{array}{l}\text { Write out short term and } \\
\text { long term goals }\end{array}$ & $56(44.8)$ & $20(16)$ & $22(17.6)$ & $12(9.6)$ & $15(12)$ \\
\hline $\begin{array}{l}\text { Studying at least } 2 \text { hours for } \\
\text { each hour of class }\end{array}$ & $66(52.8)$ & $29(23.2)$ & $11(8.8)$ & $11(8.8)$ & $8(6.4)$ \\
\hline
\end{tabular}

The mean score of students for Time management was $7.94 \pm 4.03$ with range $4-19$ (The maximum possible score was 20 for this domain). Regarding time management, majority students stated that they never use any calendar book for recording daily and weekly activities or prepare to do lists. Also it was found that most of the students did not have the habit of writing short term and long term goals.

Table 7: Assessment of domain scores according to Gender

\begin{tabular}{|c|c|c|c|c|}
\hline DOMAIN & $\begin{array}{c}\text { MALE } \\
\text { MEAN } \pm \text { SD }\end{array}$ & $\begin{array}{c}\text { FEMALE } \\
\mathrm{MEAN} \pm \mathrm{SD}\end{array}$ & Z TEST & P VALUE \\
\hline TEXT BOOK READING & $19.15 \pm 4.81$ & $20.28+4.70$ & 1.32 & $>0.05$ \\
\hline NOTES TAKING & $8.79 \pm 3.28$ & $11.32 \pm 3.19$ & 4.36 & $<0.05$ \\
\hline MEMORY & $14.24 \pm 3.93$ & $15.94 \pm 4.60$ & 2.36 & $<0.05$ \\
\hline TEST PREPARATION & $20.72 \pm 4.87$ & $22.92 \pm 4.83$ & 2.53 & $<0.05$ \\
\hline CONCENTRATION & $25.67 \pm 5.06$ & $26.91 \pm 3.76$ & 1.53 & $>0.05$ \\
\hline TIME MANAGEMENT & $6.77 \pm 3.72$ & $8.95+4.05$ & 3.16 & $<0.05$ \\
\hline
\end{tabular}


When the domains were assessed gender wise, the mean score for notes taking was higher among females $(11.32 \pm 3.19)$ than males $(8.79 \pm 3.28)$ and this difference was found to be statistically significant. Similarly the mean scores for memory, text preparation and time management were better among females than males and were also found to be statistically significant.

\section{Discussion}

The findings from our study revealed that, the main problems among students were time management, concentration, note taking and test preparation. Similar results were reported by Nagaraj and Pradeep in their study on medical students, where the major defects in the study skills of the students were planning and time management followed by concentration and note taking skills. ${ }^{(4)}$ Nourianet al. evaluated the study habits and skills in medical students and interns using a general information questionnaire and a specific researcher developed validated questionnaire on study skills and found that medical students had a problem with time management, concentration, reading speed, note taking, study habits and comprehension. ${ }^{(5)}$ Similar results were also reported in a study done by Stark in 2008. ${ }^{(6)}$ It has been shown that possessing a scheduled plan, profound study along with concentration can improve learning in medical students (Reid et al., 2005). ${ }^{(7)}$ In our study it was also observed that females had better mean scores than males in all the domains. A consistent finding in the literature is that women tend to perform better than men in their medical training. ${ }^{(8)}$

\section{Recommendations}

Study skills among students can be improved further by better time management and test preparation. Applying study skills leads to better student learning. Conducting study skill classes for the medical students would help in improving their academic performance.The didactic portion of the course is to be supplemented with other teaching learning methods like group discussions, role plays and demonstrations.

\section{References}

[1]. Mandal A, Ghosh A, Sengupta G, Bera T, Das N,Mukherjee S. Factors affecting the performance of undergraduate medicalstudents: A perspective. Indian J Community Med 2012;37:126-9.

[2]. Drew S, Bingham R. The student skill guide. Gower;1998.

[3]. 11/91rev12/02, 9/08, 3/10 Developed by Dennis H Congos, Academic Advisor and Learning Skills Specialist, First Year Advising andExploration, 116 Phillips Hall, University of Central Florida, OrlandoFL, 32816 407 - 823-3789. Email: dcongos@mail.ucf.edu.

[4]. Nagaraj C, Pradeep BS. Why do medical studentsunder-perform? A cross-sectional study from KempeGowda Institute ofMedical Sciences, Bangalore. J NTR Univ Health Sci 2014;3:92-6

[5]. Nourian A, Mousavinasab SN, Fehri A, Mohammadzadeh A, Mohammadi J. Evaluation of study skills and habits in medical students. S East Asian J Med Educ 2008;2-1:61-4.

[6]. Stark, Mary C. (2008) Retention, Bonding, andacademic Achievements: Effectiveness of thecollege's seminar in promoting college success,Ninth Annual National Conference on Retention, NewYork.

[7]. Reid, W.A., Duvall, E. \& Evans, P. (2005) Can weinfluence medical students' approaches to learning?Medical Teacher, 27(5), 401407.

[8]. Eamonn Ferguson, David James, Laura Madeley.Factors associated with success in medical school:systematic review of the literature: BMJ VOLUME 32420 APRIL 2002 